\title{
Phospholipase D Activity is Elevated in Hepatitis C Virus Core Protein-Transformed NIH 3T3 Mouse Fibroblast Cells
}

\author{
Joonmo Kim ${ }^{1}$, Eun Young Jung ${ }^{2}$, Kyung Lib Jang ${ }^{2}$ and Do Sik Min ${ }^{1 *}$ \\ ${ }^{I}$ Department of Physiology, College of Medicine, The Catholic University of Korea, Seoul 137-701, Korea \\ 'Department of Microbiology, College of Natural Sciences, Pusan National University, Busan 609-735, Korea
}

\begin{abstract}
Hepatitis $\mathrm{C}$ Virus $(\mathrm{HCV})$ is associated with a severe liver disease and increased frequency in the development of hepatocellular carcinoma. Overexpression of $\mathrm{HCV}$ core protein is known to transform fibroblast cells. Phospholipase D (PLD) activity is commonly elevated in response to mitogenic signals, and PLD has been also reported to be overexpressed and hyperactivated in some human cancer. The aim of this study was to understand how PLD can be regulated in $\mathrm{HCV}$ core protein-transformed NIH3T3 mouse fibroblast cells. We observed that in unstimulated state, basal PLD activity was higher in NIH3T3 cells overexpressing HCV core protein than in vector-transfected cells. Although expression of PLD and protein kinase C (PKC) in core protein-transformed cells was similar with that of control cells, phorbol 12-myristate 13-acetate (PMA), which is known to activate PKC, stimulated significantly PLD activity in core protein-transformed cells, compared with that of the control cells. PLD activity assay using PKC isozyme-specific inhibitor, and PKC translocation experiment showed that PKC- $\delta$ was mainly involved in the PMA-induced PLD activation in the core-transformed cells. Taken together, these results suggest that PLD might be implicated in core protein-induced transformation.
\end{abstract}

Key words - PLD, HCV core, PKC

\section{Introduction}

The hepatitis $\mathrm{C}$ virus (HCV) is the etiologic agent of acute and chronic hepatitis affecting more than 100 million people worldwide[23]. Chronic hepatitis is one of the leading causes of liver cirrhosis and hepatocellular carcinoma[20]. However, roles and mechanism of HCV in the development of this cancer has not been elucidated. HCV, a member of the flavivirus family, has a 9.5-kb positive single-stranded RNA genome, which encodes a polyprotein that is processed into at least 10

*To whom all correspondence should be addressed

Tel : 82-2-590-1165, Fax : 82-2-532-9575

E-mail: dsmin@cmc.cuk.ac.kr different structural and nonstructural proteins[18]. Core protein is a structural protein of $\mathrm{HCV}$ and it is derived from the $\mathrm{N}$-terminus of the polypeptide and has a highly basic $\mathrm{N}$-terminal region and a highly hydrophobic Cterminus. This multifunctional protein has also been implicated in hepatocyte proliferation and transformation. However, its role in cellular proliferation and tumorogenesis has not been well understood.

Phospholipase D (PLD) catalyzes the hydrolysis of phosphatidylcholine $(\mathrm{PC})$, the major membrane phospholipid, to form phosphatidic acid (PA) and choline. PA is generally recognized as the signaling product of PLD and functions as an effector in multiple physiological processes[14,22]. To date, two PLD isoforms, PLD1 and 
PLD2, have been cloned and characterized[3, 6]. PLD1 has a low basal activity and is up-regulated by small $G$ proteins (ARF, Rho and Ral), protein kinase C (PKC), and phosphatidylinositol 4, 5-bisphosphate $\left(\mathrm{PIP}_{2}\right)$ in vitro. In contrast, PLD2 has a high basal activity, requires $\mathrm{PIP}_{2}$, and is up-regulated by ARF and PKC. It was reported that the ARF-dependent nuclear PLD activity was increased in the S-phase of the regenerating rat liver after partial hepatectomy and also was much higher in AH 7974 cells than in the resting rat liver[2]. These results suggested that the nuclear ARF-dependent PLD activity may be associated with cell proliferation. It has been reported that PLD activity is significantly elevated in human cancer tissues[23-25] as well as oncogenetransformed cells $[4,5,8]$. Moreover, we reported that overexpression of PLD isozymes in fibroblast cells was associated with neoplastic transformation and tumorigenesis[16]. These results suggest that PLD might play a critical role in regulating cell responses that contribute to mitotic signaling and transformation. Recently, Jung et al. have demonstrated that overexpression of $\mathrm{HCV}$ core protein induce transformation of murine fibroblast cells [9]. In the present study, we demonstrate for the first time that PLD activity is upregulated in $\mathrm{HCV}$ core protein-transformed cells.

\section{Materials and Methods}

\section{Materials}

Dulbecco's modified Eagle's medium (DMEM) and fetal bovine serum were purchased from Invitrogen. The antibodies to PKC- $\alpha$, PKC- $\delta$, and PKC- $\zeta$ were purchased from Santa Cruz. PKC isozyme-specific inhibitors (Gö6976, Rottlerin) were from Calbiochem. Rabbit polyclonal antibody that recognizes both PLD1 and PLD2 was generated as described previously[13]. Phosphatidylbutanol standard was from Avanti Polar Lipid. $\left[9,10-{ }^{3} \mathrm{H}\right]$ myristate were purchased from PerkinElmer Life Sciences. Silica gel $60 \mathrm{~A}$ thin layer chromatography plates were from Whatman. Horseradish peroxidase-conjugated anti-mouse IgG and anti-rabbit IgG were from Kirkegaard \& Perry Laboratory (Gaithersburg, MD). The ECL Western blotting detection kit was from Amersham Biosciences.

\section{Establishment of Stable cell lines}

Stable NIH3T3 cells overexpressing HCV core protein were established as described previously (Han et al., 2002). Construction of pCI-neo-core K (genotype $1 \mathrm{~b}$ ) was made. Stable NIH3T3 cell lines following transfection with the plasmid were generated and the cells were grown in DMEM supplemented with $10 \%$ (v/v) fetal bovine serum and $500 \mu \mathrm{g} / \mathrm{ml} \mathrm{G} 418$ under $5 \% \mathrm{CO}_{2}$.

\section{Phospholipase D Activity Assay}

PLD activity was assessed by measuring the formation of $\left[{ }^{3} \mathrm{H}\right]$ phosphatidylbutanol (PtdBut), the product of PLD-mediated transphosphatidylation, in the presence of 1-butanol. Cells were subcultured in 6-well plates at $2 \times$ $10^{5}$ cells/well and serum-starved in the presence of $1 \mu \mathrm{Ci}$ $\mathrm{ml}\left[{ }^{3} \mathrm{H}\right]$ myristic acid. After overnight starvation, the cells were washed three times with $5 \mathrm{ml}$ of phosphatebuffered saline (PBS) and pre-equilibrated in serum-free DMEM for $1 \mathrm{~h}$. For the final $10 \mathrm{~min}$ of preincubation, $0.3 \%$ butan-1-ol was included. At the end of the preincubation, cells were treated with agonists for the indicated times. The extraction and characterization of lipids by thin-layer chromatography were performed as previously described[1].

\section{Immunoprecipitation}

Cells were harvested and lysed with lysis buffer $(20$ mM Hepes, pH 7.2, 1\% Triton X-100, 1\% sodium deoxycholate, $0.2 \%$ SDS, $150 \mathrm{mM} \mathrm{NaCl}, 1 \mathrm{mM} \mathrm{Na}_{3} \mathrm{VO}_{4}, 1$ $\mathrm{mM} \mathrm{NaF}, 10 \%$ glycerol, $10 \mu \mathrm{g} / \mathrm{ml}$ leupeptin, $10 \mu \mathrm{g} / \mathrm{ml}$ aprotinin, $1 \mathrm{mM}$ phenymethylsulfonyl fluoride). The cells were then centrifuged at $10,000 \times \mathrm{g}$ for $1 \mathrm{~h}$, and the resulting supernatant was incubated on anti-PLD or anti-PKC antibody and protein A sepharose for $4 \mathrm{~h}$ at 
Phospholipase D Activity is Elevated in Hepatitis C Virus Core Protein-Transformed NIH 3T3 Mouse Fibroblast Cells

$4^{\circ} \mathrm{C}$ with rocking. Protein concentrations were determined using the BioRad Protein Assay with bovine serum albumin as a standard. The immune complexes were collected by centrifugation and washed five times with a buffer (20 mM Tris, pH 7.5, 1 mM EDTA, $1 \mathrm{mM}$ EGTA, $150 \mathrm{mM} \mathrm{NaCl}, 2 \mathrm{mM} \mathrm{Na} \mathrm{VO}_{4}, 10 \%$ glycerol and $1 \%$ Nonidet $\mathrm{P}-40$ ) and resuspended in sample buffer. The final pellet was loaded onto a polyacrylamide gel for immunoblot analysis.

\section{Western blotting}

Proteins samples were analyzed by SDS-polyacrylamide gel electrophoresis on $8 \%$ gels and were transferred to a nitrocellulose membrane. The blots were then blocked with 5\% non-fat milk and incubated with appropriate primary antibodies followed by incubation with horseradish peroxidase-conjugated secondary antibody. Immunoreactive bands were detected using enhanced chemiluminescence.

\section{Subcellular Fractionation}

The cells were harvested and washed twice with ice-cold lysis buffer (20 mM Hepes, pH 7.4, 10\% glycerol, $1 \mathrm{mM}$ EDTA, $1 \mathrm{mM}$ EGTA, $1 \mathrm{mM}$ of dithiothreitol, and $1 \mathrm{mM}$ phenylmethylsulfonyl fluoride and $10 \mu \mathrm{g} / \mathrm{ml}$ leupeptin). The cells were then resuspended in lysis buffer and lysed by ten passages through a 25-gauge needle. Trypan blue staining of the lysate indicate $>95 \%$ disruption of the cells. The cell lysate was first spun at $500 \times \mathrm{g}$ for $10 \mathrm{~min}$ to remove unbroken cells. The supernatant was then spun at $100,000 \times \mathrm{g}$ for $1 \mathrm{~h}$ at $4^{\circ} \mathrm{C}$ to separate the cytosolic and membrane fractions. Membrane fractions were washed twice with the buffer to remove cytosolic proteins.

\section{Results}

PLD activity is enhanced in NIH3T3 cells overexpressing HCV Core protein

To investigate whether PLD activity is regulated in
$\mathrm{HCV}$ core protein-transformed cells, we tried to perform PLD activity assay in HCV core protein-transformed cells and vector-transfected cells. In unstimulated condition, basal PLD activity was higher in core protein-transformd cells than in control cells. PMA as a mitogen is known to activate PKC isoforms and then PLD. As shown in Fig. 1A, PMA-induced PLD activation was also significantly higher in the transformed cells than control cells. Significant increase of PMA-induced PLD activity in core protein-transformed cells occurred in a time dependent manner, compared with that of control cells (Fig. 1B). These result demonstrate that PLD activity is upregulated in core protein-transformed cells.
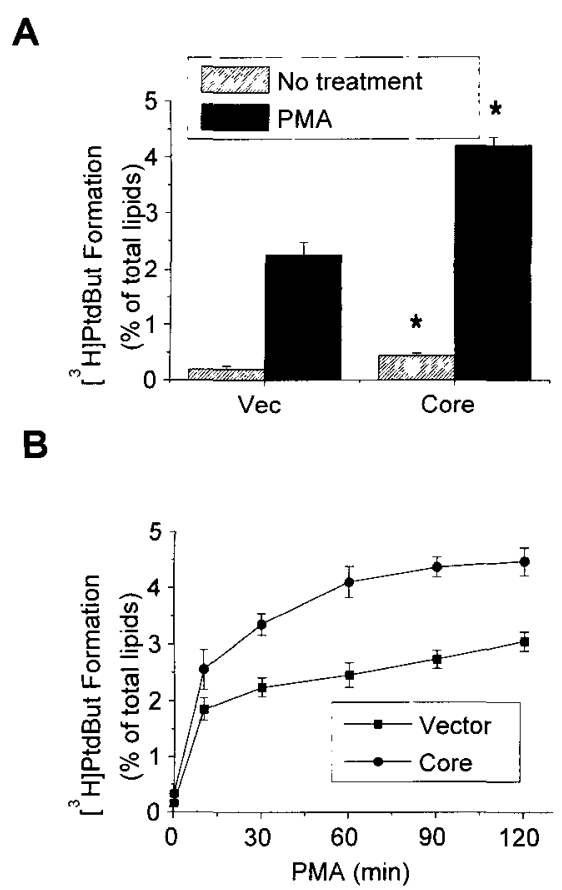

Fig. 1. Overexpression of $\mathrm{HCV}$ core protein enhances PMA-induced PLD activity.

A. NIH3T3 fibroblasts overexpressing $\mathrm{HCV}$ core as well as vector-transfected cells were cultured in six-well plates, labeled with $\left[{ }^{3} \mathrm{H}\right]$ myristate, and treated with PMA $(100 \mathrm{nM})$ for $60 \mathrm{~min}$. B. Vector and coretransformed cells were treated with PMA for different times. ${ }^{*} p<0.05$ compared to cells transfected with vector and treated with or without PMA The radioactivity incorporated into phosphatidylbutanol was measured as described under "Materials and Methods". Results are the means $\pm \mathrm{SD}$ of three independent experiments. 
PLD1 and PKC is in a similar level expressed in both core protein and vector-transfected cells

To examine whether upregulation of PLD activity may be due to enhanced expression of PLD or PKC protein, we tried to investigated the expression level of the proteins. We found that vector and core protein-transfected cells expressed similar levels of PLD1 by immunoprecipitation and western blot analysis using an antiPLD antibody (Fig. 2). However, PLD2 was not detected in either cells (data not shown), indicating that the PLD activity shown in these cells may be due mainly to PLD1. In addition, Using immunoblotting with PKC isozyme-specific antibodies we investigated which PKC isozymes were expressed in the cells. We found that PKC- $\alpha$ (a conventional PKC), PKC- $\delta$ (a novel PKC), and PKC- $\zeta$ (atypical PKC) were predominantly expressed and among them PKC- $\alpha$ was highly expressed in these two kinds of cells. Both vector and core protein-transformed

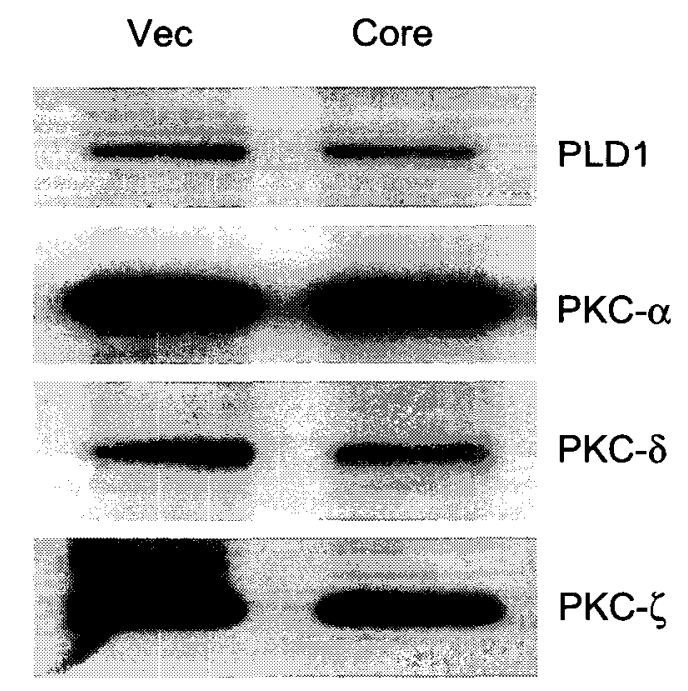

Fig. 2. Expression of PLD1 and PKC isozymes in NIH3T3 fibroblasts.

Vector or core overexpressing cells were lysed, and immunoprecipitates (IP) were prepared using anti-PLD, anti-PKC- $\alpha$, anti-PKC- $\delta$, or anti-PKC- $\zeta$ antibodies. Immune complexes were analyzed by SDS-polyacrylamide gel electrophoresis, followed by transfer of proteins to nitrocellulose membrane and Western blotting (Blot) with the indicated antibody. The results shown are representative of three separate experiments. cells showed similar level of PKC isozymes expression. These results suggest that enhanced PLD activity in core protein-transformed cells may be not due to upregulation of PLD and PKC proteins.

PKC- $\delta$ is mainly involved in PMA-induced PLD activation in HCV core protein-transformed cells

To determine which isozymes of PKC are involved on PMA-stimulated PLD activation in NIH3T3 cells overexpressing HCV core protein, we used PKC isozymespecific inhibitors (Fig. 3). Pretreatment of calcium dependent PKC inhibitor (Gö6976) inhibited mildly PMAinduced PLD activation. In contrast, PMA-induced PLD activation was suppressed dramatically in dose dependent manner by pretreatment of PKC $\delta$ specific inhibitor (Rottlerin). These results show that in core-transformed cells, PKC- $\delta$ might be mainly involved in PMAstimulated PLD.

PMA induced more rapidly translocation of PKC$\delta$ from cytosol to membrane fraction than that of PKC- $\alpha$ in core-transformed cells

To confirm that PKC- $\delta$ is mainly involved in PMA-

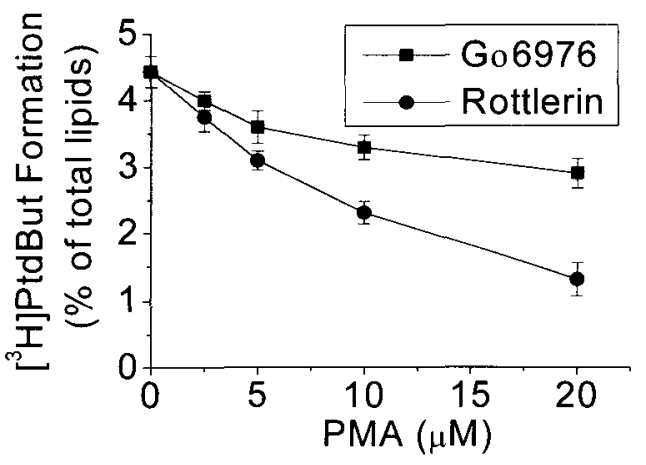

Fig. 3. PKC- $\delta$ is mainly involved in the PMA-induced PLD activation in core-transformed cells.

The core-transformed cells were pretreated with various $\mathrm{PKC}$ inhibitors in the indicated concentration for $30 \mathrm{~min}$ and stimulated with $100 \mathrm{nM}$ PMA for $60 \mathrm{~min}$. Radioactivity incorporated into phosphatidylbutanol was measured as described under "Materials and Methods". Results are the means $\pm S D$ of three independent experiments. 
induced PLD activation than PKC- $\alpha$ in HCV core proteintransformed cells, we tried to investigate translocation of the PKC isozyme. Subcellular fractionation and westernblot analysis were performed. As shown in Fig. 4, treatment of PMA induced gradually translocation of PKC- $\alpha$ from cytosol to membrane fraction in time dependent manner, whereas all the PKC- $\delta$ was rapidly translocated to membrane fraction after PMA treatment. Taken together with the result about effect of PKC inhibitor, this result suggests that $\mathrm{PKC}-\delta$ might be mainly involved in PMA-stimulated PLD activation in HCV core proteintransformed fibroblasts.

\section{Discussion}

In the present study, we demonstrated for the first time that overexpression of $\mathrm{HCV}$ core protein in NIH3T3 fibroblasts upregulated PLD activity. PLD activity has been found to be markedly elevated in various cancer

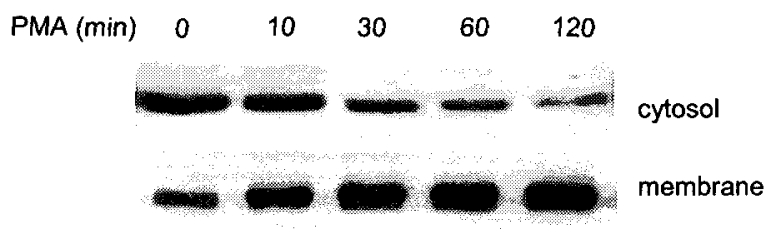

Blot: PKC- $\alpha$

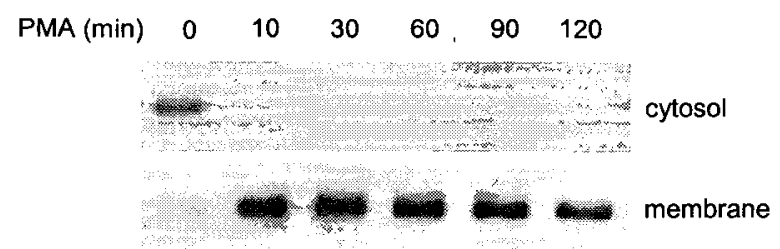

Blot: PKC- $\delta$

Fig. 4. PMA induced more rapidly translocation of PKC$\delta$ from cytosol to membrane fraction than that of PKC- $\alpha$ in core-transformed cells

Serum-starved cells were treated with $100 \mathrm{nM}$ PMA for the indicated times. Lysates were fractionated into the cytosolic and membrane fractions. Each fraction was immunoblotted using antibodies specific for PKC$\alpha$ and PKC- $\delta$. The results shown are representative of three separate experiments. tissues[24-26], multidrug resistant cancer cells[4], and transformed cells[5,8]. Recently, we demonstrated that overexpression of PLD isozyme induced tumorigenic transformation of fibroblasts[16], and transmodulation between PLD and c-Src enhanced cell proliferation[1]. Therefore, it is suggested that PLD may play a pivotal role in the signal transduction pathways of cellular proliferation and carcinogenesis. Hepatocellular carcinoma (HCC) is one of the most common human cancers in a worldwide basis. Among the several risk factors, chronic infection with either hepatitis $C$ virus is closely related to the development of HCC. HCV core protein has been considered to play important roles during development of $\mathrm{HCC}$ by HCV[11]. Core protein demonstrated its tumorigenecity by inducing $\mathrm{HCC}$ in vivo in transgenic mice[17]. As multifunctional regulator, core protein is known to deregulate cell cycle checkpoints by modulating transcription of the p21 gene[10]. In addition, it can activate the expression of some proto-oncogenes[19]. Furthermore, it might modulate mitogenic intracellular signaling pathways as well as apoptotic pathways leading to cell death by interacting several signaling molecules[15,21]. Recently, our colleague have reported that overexpresion of $\mathrm{HCV}$ core protein induced transformation of fibroblasts[9]. Therefore, we tried to investigate a possibility that PLD activity might be affected in the core-transformed fibroblasts. In this study, we found that PMA-induced PLD activity as well as basal activity were enhanced in the transformed cell with HCV core protein than that of control cells. Both control and core-transformed cells expressed PLD1 protein, but PLD2 isozyme was not detected by antibody to PLD (data not shown). These cells showed no difference in PLD1 expression. Both thesea, PKC- $\alpha$, PKC- $\delta$ and PKC- $\zeta$ and the expression level of PKC- $\alpha$ was very high. Using PKC isozyme-specific inhibitors, we found that in coretransformed cell, PKC- $\delta$ was mainly involved in the PMA-induced PLD activation. Inhibitor of PKC- $\zeta$ did not affect PLM-induced PLD activation (data not shown). 
Moreover, PMA induced rapidly translocation or activation of PKC- $\delta$ from cytosol to membrane fraction, whereas PKC- $\alpha$ was gradually translocated into membrane fraction, supporting PKC- $\delta$ is significantly involved in PMA-induced PLD activation in core-transformed cells.

Since both PLD and HCV core protein have been implicated in the cell proliferation and tumorigenesis, it is possible that PLD and HCV core cooperate by acting at different stages to make a cell to pass some of the multi-step required for hepatocarcinogenesis. However, roles of PLD signaling in tumorigenesis of core protein-transformed cells requires further study.

In the present study, we demonstrated for the first time upregulation of PLD activity in core-transformed cells. These result might provide a clue to understand signaling network for the promotion and /or progression of cancers via PLD and HCV core.

\section{Acknowledgments}

This work was supported by a grant from BioGreen 21 Program, Rural Development Administration, Republic of Korea.

\section{References}

1. Ahn, B. H., S. Y. Kim, E. H. Kim, K. S. Choi, T. K. Kwon, Y. H. Lee, J. S. Chang, M. S. Kim, Y. H. Jo and D. S. Min. 2003. Transmodulation between phospholipase D and c-Src enhances cell proliferation. Mo.l Cell. Biol. 23, 3103-3115.

2. Banno, Y, K., Tamiya-Koizumi, H. Oshima, A. Morikawa, S. Yoshida and Y. Nozawa. 1997. Nuclear ADP-ribosylation factor (ARF)- and oleate-dependent phospholipase D (PLD) in rat liver cells. Increases of ARF-dependent PLD activity in regenerating liver cells. J. Biol. Chem. 272, 5208-5213.

3. Colley, W. C., T. C. Sung, R. Roll, J. Jenco, S. M. Hammond, Y. Altshuller, D. Bar-Sagi, A. J. Morris and M. A. Frohman. 1997. Phospholipase D2, a distinct phospholipase D isoform with novel regulatory properties that provokes cytoskeletal reorganization. Curr. Biol. 7, 191-201.

4. Fiucci, G., M., Y. Czarny, Y. Lavie, D. Zhao, B. Berse, J. K. Blusztajn and M. Liscovitch. 2000. Changes of phospholipase D isoform activity and expression in multidrug-resistant human cancer cells. Int. J. cancer. 85, 882-888.

5. Frankel, P., M. Ramos, J. Flom, S. Bychenok, T. Joseph, E. Kerkhoff, U. R. Rapp, L. A. Feig and D. A. Foster. 1999. Ral and Rho-dependent activation of phospholipase D in v-Raf-transformed cells. Biochem. Biophys. Res. Commun. 255, 502-507.

6. Hammond, S. M., J. M. Jenco, S. Nakashima, K. Cadwallader, Q. Gu, S. Cook, Y. Nozawa, G. D. Prestwich, M. A. Frohman and A. J. Morris. 1997. Characterization of two alternately spliced forms of phospholipase D1. Activation of the purified enzymes by phosphatidylinositol 4,5-bisphosphate, ADPribosylation factor, and Rho family monomeric GTPbinding proteins and protein kinase C- $\alpha$.J. Biol. Chem. 272, 3860-3868.

7. Han, H. J., E. Y. Jung, W. J. Lee and K. L. Jang. 2002. Cooperative repression of cyclin-dependent kinase inhibitor p21 gene expression by hepatitis B virus $X$ protein and hepatitis $C$ virus core protein. FEBS Lett. 518, 169-172.

8. Jiang, Y. W., J. Song, Q. Zhang and D. A. Foster. 1994. Phosphatidylcholine-specific phospholipase D activity is elevated in v-Fps-transformed cells. Biochem. Biophys. Res. Commun. 203, 1195-1203.

9. Jung, E. Y., H. K. Kang, J. Chang, D.Y. Yu and K. L. Jang, 2003. Cooperative transformation of murine fibroblast NIH3T3 cells by hepatitis C virus core protein and hepatitis B virus X protein. Virus Res. 94, 79-84.

10. Jung, E. Y., M. N. Lee, H. Y. Yang, D. Yu and K. L. Jang. 2001. The repressive activity of hepatitis $C$ virus core protein on the transcription of p21 (waf1) is regulated by protein kinase A-mediated phosphorylation. Virus Res. 79, 109-115.

11. Koike, K., K. Tsutsumi, H. Fujie, Y. Shintani and M. Kyoji. 2002. Molecular mechanism of viral hepatocarcinogenesis. Oncology 62 (Suppl 1), 29-37.

12. Kunkel, M. and S. J. Watowich. 2000. Conformational changes accompanying self-assembly of the hepatitis C virus core protein. Virology 294, 239-245. 
Phospholipase D Activity is Elevated in Hepatitis C Virus Core Protein-Transformed NIH 3T3 Mouse Fibroblast Cells

13. Lee, M.-Y., Y. J. Jo, M. H. Chun, J. W. Chung, M. S. Kim and D. S. Min. 2000. Immunohistochemical localization of phospholipase D1 in rat central nervous system. Brain Res. 864, 52-59.

14. Liscovitch, M., M. Czarny, G. Fiucci and X. Tang. 2000. Phospholipase D: molecular and cell biology of a novel gene family. Biochem. J. 345, 401-415.

15. Marusawa, H., M. Hijikata, T. Chiba and K. Shimotohno. 1999. Hepatitis C virus core protein inhibits Fas- and tumor necrosis factor alpha-mediated apoptosis via NF-kappaB activation. J. Virol. 73, 47134720 .

16. Min, D. S., T. K. Kwon, W. S. Park, J. S. Chang, S. K. Park, B. H. Ahn, Z. Y. Ryoo, Y. H. Lee, Y. S. Lee, D. J. Rhie, S. H. Yoon, S. J. Hahn, M. S. Kim and Y. H. Jo. 2001. Neoplastic transformation and tumorigenesis associated with overexpression of phospholipase D isozymes in cultured murine fibroblasts. Carcinogenesis 22, 1641-1647.

17. Moriya, K., H. Fujie, Y. Shintani, H. Yotsuyanagi, T. Tsutsumi, K. Ishibashi, Y. Matsuura, S. Kimura, T. Miyamura and K. Koike. 1998. The core protein of hepatitis $\mathrm{C}$ virus induces hepatocellular carcinoma in transgenic mice. Nat. Med. 4, 1065-1067.

18. Ray, R. B. and R. Ray. 2001. Hepatitis C virus core protein: intriguing properties and functional relevance. FEMS Microbiol. Lett. 202, 149-156.

19. Ray, R. B., R. Steele, K. Meyer and R. Ray. 1997. Transcriptional repression of $\mathrm{p} 53$ promoter by hep- atitis C virus core protein. J. Biol. Chem. 272, 1098310986.

20. Saito, T., A. Miyamura, H. Ohbayashi, T. Harada, T. Katayama, S. Kikuchi, Y. Watanabe, S. Koi, M. Onji, Q.-L. Choo, M. Houghton and G.. Kuo. 1990. Hepatitis $C$ virus infection is associated with the development of hepatocellular carcinoma. Proc. Natl. Acad. Sci. USA 87, 6547-6549.

21. Shiravastava, A., S. K. Manna and R. Ray. 1998. Ectopic expression of hepatitis $\mathrm{C}$ virus core protein differentially regulates nuclear transcription factors. $J$. Virol. 72, 9722-9728.

22. Steed, P. M. and A. H. M. Chow. 2001. Intracellular signaling by phospholipase $\mathrm{D}$ as therapeutic target. Curr. Pharmaceu. Biotech. 2, 241-256.

23. Uchida, T. 1994. Pathology of hepatitis C. Intervirology 37, 126-132.

24. Uchida, N., S. Okamura and H. Kuwano. 1999. Phospholipase D activity in human gastric carcinoma. Anticancer Res. 19, 671-676.

25. Uchida, N., S. Okamura and Y. Nagamachi. 1997. Increased phospholipase D activity in human breast cancer. J. Cancer Res. Clin. Oncol. 13, 280-285.

26. Zhao, Y., H. Ehara, Y. Akao, M. Shamato, Y. Nakagawa, Y. Banno, T. Deguchi, N. Ohishi, K. Yaki and Y. Nozawa. 2000. Increased activity and intracellular expression of phospholipase D in human renal cancer. Biochem. Biophys. Res. Commun. 278, 140143.

(Received August 6, 2003; Accepted October 1, 2003) 


\title{
초록 : C형 간염바이러스의 core 단백질에 의해 암화된 쥐의 섬유아세포에서 phospholipase D 효소활성의 증가
}

\author{
김준모 ${ }^{1} \cdot$ 정은영 ${ }^{2} \cdot$ 장경립 ${ }^{2} \cdot$ 민도식 $^{1}$ \\ ('가톨릭대학교 의과대학 생리학교실, ${ }^{2}$ 부산대학교 자연과학부 미생물학과)
}

C형 간염바이러스는 간암을 야기하는 심각한 바이러스이다. C형 간염바이러스의 core 단백질의 과발현 은 섬유아세포를 암화시키는 것으로 알려져 있다. Phospholipase D (PLD)의 호소활성이 세포증식 신호전달 에 의해 활성화되어 있으며, 사람의 암조직에서 과발현 및 활성이 증가되어 있는것으로 알려져 있다. 본 연 구의 목적은, core 단백질에 의해 암화된 세포에서 PLD가 어떻게 조절되는지롤 이해하고자 하는것이다. 자 극이 없는 상태에서뿐만 아니라 PMA에 의해 유도되는 PLD효소활성은, 암화된 세포에서 더 증가하였으며, control 세포와 core 단백질에 의해 암화된 세포에서 PLD와 PKC 단백질의 발현은 서로 유사하였다. PKC 특이적인 억제제와 PKC의 세포막으로의 이동에 관한 실험을 통해서, PKC-d가 암화된 세포에서 PMA에 의 해 유도되는 PLD활성의 증가에 중요하게 관여하고 있음을 밝혔다. 이러한 결과는, PLD가 core 단백질에 의 해 유도되는 세포의 암화과정에 관여하고 있을것으로 추정된다. 